\title{
Metody oceny integracji implantów zębowych z tkanką kostną - przegląd piśmiennictwa
}

\author{
Methods for evaluating the integration of dental implants with bone - literature review \\ ${ }^{1}$ Specjalistyczne Gabinety Stomatologiczne LRM w Poznaniu \\ ${ }^{2}$ Klinika Gerostomatologii, Uniwersytet Medyczny im. Karola Marcinkowskiego w Poznaniu
}

DOI: http://dx.doi.org/10.20883/df.2017.6

\begin{abstract}
Streszczenie
Rehabilitacja narządu żucia przy użyciu implantów dentystycznych jest jedną z najnowocześniejszych metod terapii rekonstrukcyjnej o wysokim odsetku powodzenia. Determinantą sukcesu terapii implantoprotetycznej jest między innymi osiągnięcie stabilności wszczepów śródkostnych. Ocena stabilizacji implantów stanowi zatem ważną procedurę zabiegową, ułatwiając lekarzowi podjęcie decyzji o obciążeniu wszczepów odbudową protetyczną i minimalizując ryzyko niepowodzenia leczenia. Celem pracy jest przedstawienie czynników wpływających na stabilizację pierwotną wszczepu oraz prezentacja najpopularniejszych metod oceny stabilizacji wszczepów śródkostnych.
\end{abstract}

Słowa kluczowe: osteointegracja, stabilizacja pierwotna, stabilizacja wtórna, sukces implantologiczny.

\begin{abstract}
Rehabilitation of the stomatognathic system through the use of dental implants is one of the most up-to-date methods of reconstructive therapy and it is characterized by a high success rate. A successful result of implant-prosthetic therapy is determined mainly by the stability of intraosseous implants. Therefore, the evaluation of implant stability is an important treatment component by allowing the dentist to decide whether or not to load the implant along with the restoration, thus minimizing the risk of failure. The paper discusses factors affecting primary implant stability and presents the most common methods for evaluating intraosseous implant stability.
\end{abstract}

Keywords: osseointegration, primary stability, secondary stability, implantation success rate.

Osteointegracja jest zjawiskiem mającym zasadniczy i nierozerwalny związek z uzyskaniem pozytywnego efektu terapii implantoprotetycznej.

Pomiary stabilności implantów zębowych przeprowadzane podczas wizyt kontrolnych mają istotne znaczenie kliniczne i umożliwiają ochronę potencjalnie zagrożonych wszczepów śródkostnych przed ich utratą.

Szereg dostępnych na rynku narzędzi pozwala monitorować proces zakotwiczenia śródkostnych implantów, ułatwiając lekarzowi podjęcie decyzji o momencie obciążenia wszczepów dentystycznych suprastrukturą protetyczną. Jednakże zarówno przyrządy, jak i metody oceny stabilności implantów dentystycznych, dostarczające informacji na temat stanu miejscowego nie są doskonałe, a spopularyzowanie leczenia z wykorzystaniem wszczepów śródkostnych wymaga ciągłego ulepszania sposobu oceny stabilności implantów zębowych.

\section{Stabilizacja pierwotna}

Pozytywny wynik osteointegracji, czyli zjawiska polegającego na bezpośrednim połączeniu żywej tkanki kostnej z powierzchnią wszczepu śródkostnego, uzależniony jest od stabilizacji pierwotnej i wtórnej implantu dentystycznego. Stabilizacja pierwotna wynika z mechanicznego umocowania wszczepu w tkance kostnej na zasadzie wklinowania implantu o określonej powierzchni i kształcie w kość wyrostka zębodołowego. Jest wiec kluczowym zjawiskiem dla osiągnięcia stabilizacji wtórnej. Wg opinii Albrektssona z 1981 r., stabilizacja pierwotna warunkuje rozwój i utrzymanie osteointegracji [1]. Stanowi więc determinantę sukcesu terapii implantoprotetycznej [2]. W piśmiennictwie anglojęzycznym określana jest jako brak ruchomości implantu w łożu kostnym bezpośrednio po jego wszczepieniu. Na wykorzystaniu zjawiska pierwotnej stabilizacji opiera się metoda natychmiastowej implantacji, polegająca na wprowadzeniu wszczepu śródkostnego w łoże zębodołu usuniętego uprzednio zęba, jednak nie wcześniej niż po siedmiu dniach wstecz.

Czynniki wpływające na stabilizację pierwotną $\mathrm{Na}$ uzyskanie stabilizacji pierwotnej oraz proces wgajania i następującego po nim zjawiska osteoin- 
tegracji ma wpływ zarówno kształt implantu, jego wielkość oraz powierzchnia, jak i właściwości tkanki kostnej, takie jak jakość, którą wyraża się poprzez gęstość i grubość kości korowej, a także objętość tkanki kostnej [3-11]. Istotne znaczenie dla otrzymania pożądanej stabilności pierwotnej ma także rodzaj zastosowanej procedury chirurgicznej podczas wprowadzania implantu w łoże kostne $[5,12,13]$. Zastosowanie odpowiedniej techniki operacyjnej jest szczególnie ważne w rejonach, w których stwierdzono gorszą jakość tkanki kostnej. Doświadczenia wykazały, że wybór cieńszego frezu dla wprowadzenia wszczepu w tylny odcinek kości szczęki (często bardziej spneumatyzowanej niż w żuchwie) może znacząco poprawić wartość stabilności pierwotnej implantu poprzez większą kompresję przylegającej do niego tkanki, a w efekcie wpłynąć na długoczasowy sukces rehabilitacji implantoprotetycznej [8].

Jakościowe i ilościowe modyfikacje powierzchni implantów, zmieniające ich właściwości fizykochemiczne, mają istotny wpływ na zjawisko osteointegracji. Gładka powierzchnia wcześniej stosowanych implantów zastąpiona została chropowatą powłoką, redukującą obecność błony łącznotkankowej, pojawiającej się w środowisku połączenia wszczepu dentystycznego z tkanką kostną [14]. Powiększenie w ten sposób powierzchni wszczepu skutkuje lepszym (większym) kontaktem wszczepu z tkanką kostną i umożliwia zwiększenie wytrzymałości połączenia implant-kość na rozciąganie, co wpływa na poprawę przyszłej stabilizacji wtórnej [14]. Powierzchnia aktywna otrzymana przez powleczenie trzonu tytanowego preparatem Titan-Plasma-Flame (TPF) oddziałuje na wzrost i remodeling tkanki kostnej, zwiększając stopień stabilizacji pierwotnej [15].

Stabilizacji pierwotnej sprzyjają nie tylko zmodyfikowane powierzchnie wszczepów śródkostnych, ale również zmodyfikowane stożkowe kształty implantów, z nagwintowaniem o zwiększającej się średnicy przy wierzchołku $[9,11]$. Udowodniono, że wszczepy śródkostne o agresywnym kształcie gwintu osiągają lepszą stabilizację pierwotną niż implanty o klasycznym kształcie gwintu [16]. Taka geometria sztucznego filaru dentystycznego polepsza bowiem mechaniczne zakotwiczenie implantu w opracowanym łożu kostnym nawet przy jego niewielkim kontakcie z tkanką kostną $[6,14,17]$.

Mechaniczne utrzymanie implantu w kości wyrostka zębodołowego zwiększa się wraz ze wzrostem powierzchni kontaktu sztucznego filaru dentystycznego z tkanką kostną [18]. Wybór odpowiedniej średnicy wszczepu ma istotne znaczenie dla uzyskania dostatecznego stopnia stabilizacji pierwotnej, prowadzącej do osteointegracji im- plantu. Większa średnica wszczepu śródkostnego umożliwia bowiem kompensację niedoborów jakościowych tkanki kostnej [19].

Wszczepy śródkostne umiejscowione w różnych okolicach anatomicznych osiągają zróżnicowaną stabilizację pierwotną, zależną od ich lokalizacji. Seong i wsp. przeprowadzili badanie, polegające na pomiarze stabilności implantów wszczepionych w różne okolice szczęki i żuchwy [7]. Wynika z niego, iż wszczepy zaimplantowane w żuchwie wykazują istotnie statystycznie lepszą stabilizację pierwotną, w porównaniu z implantami wprowadzonymi w kość szczęki. Ponadto najsłabsza stabilność pierwotna charakteryzuje wszczepy dentystyczne znajdujące się w okolicy guza szczęki, i jest także mniejsza w wymiarze policzkowo-językowym niż mezjo-dystalnym. Badania te dowodzą, iż gęstość kości (zależna od regionu anatomicznego) wpływa na wynik stabilności pierwotnej wszczepów dentystycznych.

Stabilizacja pierwotna jako zjawisko wklinowania implantu w kość wyrostka zębodołowego stanowi klucz do osiągnięcia stabilności wtórnej, której charakter wynika z zaawansowania procesu osteointegracji [20]. Wraz z postępującym procesem wgajania wszczepu dentystycznego w kość wartość stabilizacji pierwotnej maleje na rzecz rozwijającej się stabilizacji wtórnej. Momentem krytycznym dla powodzenia terapii implantoprotetycznej jest 3-4 tydzień po zabiegu, gdy obniżająca się stabilizacja pierwotna nie jest jeszcze zastąpiona wystarczającą stabilizacją wtórną, wynikającą z procesu apozycji i remodelingu tkanki kostnej. Stabilizacja wtórna polega bowiem na połączeniu się osteoblastów z powierzchnią alloplastycznego filaru, a stopień integracji implantu dentystycznego z kością wyrostka zębodołowego determinuje jej wartość [21]. Osiągnięcie wymaganej stabilizacji wtórnej, wystarczającej dla obciążenia wszczepu nadbudową protetyczną, jest celem każdego zabiegu implantacji.

\section{Metody oceny stabilizacji implantów}

Pomiary stabilności wszczepów śródkostnych mają więc istotne znaczenie kliniczne, pozwalają bowiem na precyzyjne określenie momentu, w którym możliwe jest obciążenie wszczepionego implantu odbudową protetyczną, warunkującą jego funkcjonalność. Monitorowanie stopnia stabilizacji wszczepów śródkostnych ma znaczenie nie tylko podczas fazy protetycznej terapii implantologicznej, ale także podczas długoczasowej opieki pozabiegowej, gdyż umożliwia ochronę potencjalnie zagrożonych implantów przed ich utratą. Metody pomiarowe powinny zatem spełniać kilka istotnych warunków, aby mogły być standardowo stosowa- 
ne w celu prowadzenia dokumentacji rehabilitacji implantoprotetycznej. Metody pomiarowe powinny cechować:

- obiektywizm,

- nieinwazyjność,

- powtarzalność,

- porównywalność,

- nieskomplikowana obsługa [22].

Prezentowane w piśmiennictwie metody inwazyjne nie mają zastosowania w pracy klinicznej, gdyż ich mechanizm działania wiąże się ze zniszczeniem podlegającego pomiarowi połączenia implant-kość. Pomiarów stabilizacji implantów dokonać można zarówno w trakcie zabiegu implantacji (metody te dotyczą oceny uzyskanej stabilizacji pierwotnej) jak i pooperacyjnie (wówczas szacowany jest stopień stabilizacji wtórnej). Do najbardziej rozpowszechnionych metod oceny zakotwiczenia wszczepów należą [20]:

- badania radiologiczne,

- testy manualne,

- metody akustyczne,

- pomiary z zastosowaniem aparatury: Periotest,

- analiza częstotliwości rezonansowej drgań: Osstell.

\section{Metoda radiologiczna}

Diagnostyka radiologiczna jest niezmiernie ważnym elementem zarówno podczas fazy planowania zabiegu implantacji, jak i kontroli pozabiegowej. Przydatna podczas planowania leczenia, umożliwia oszacowanie jakości podłoża kostnego, co ma bezpośredni związek ze stopniem stabilizacji późniejszego wszczepu dentystycznego.

Najbardziej wartościowym badaniem, mającym największe zastosowanie $w$ diagnostyce przedzabiegowej i dostarczającym informacji na temat stanu tkanki kostnej w miejscu planowanej implantacji, jest tomografia komputerowa [23, 24]. Coraz powszechniej stosowana metoda tomografii wolumetrycznej CBCT pozwala na uzyskanie trójwymiarowego obrazu $\mathrm{w}$ technologii cyfrowej $[25,26]$, dostarczając informacji na temat warunków anatomicznych i wartości struktur kostnych oraz gęstości tkanki kostnej wyrażonej w skali Hounsfielda. Metoda ta ma jednak ograniczone zastosowanie w diagnostyce poimplantacyjnej ze względu na znacznie większą dawkę promieni rentgenowskich niż ogólnodostępna metoda konwencjonalnej radiografii, emitująca minimalne dawki promieniowania [27]. Zdjęcie zębowe obrazujące wszczep śródkostny i otaczającą go kość umożliwia analizę poziomu brzegu kości wyrostka zębodołowego, w której pogrążony jest implant. Akceptowalny rozmiar ubytku tkanki kostnej wokół wszczepu wynosi do $1 \mathrm{~mm}$ w ciągu pierwszego
Tabela 1. Skala ruchomości implantu (Sokalski, Zagalak 2002)

Table 1. Implant mobility scale (Sokalski, Zagalak 2002)

\begin{tabular}{|l|l|}
\hline stopień & \multicolumn{1}{|c|}{ ruchomość } \\
\hline 0 & brak \\
\hline 1 & nieznaczna w płaszczyźnie poziomej \\
\hline 2 & średnia $<0,5 \mathrm{~mm}$ w płaszczyźnie poziomej \\
\hline 3 & znaczna $>0,5 \mathrm{~mm}$ w płaszczyźnie poziomej \\
\hline 4 & pozioma i pionowa \\
\hline
\end{tabular}

roku po implantacji oraz $0,1 \mathrm{~mm}$ w następnych latach [20]. Zanik brzegu kostnego przekraczający te wartości może wskazywać na brak dostatecznej stabilności implantu.

O braku osteointegracji może świadczyć również obecność obwódki przejaśnienia wokół implantu. Powszechnie dostępna dwuwymiarowa radiografia wewnątrzustna posiada jednak pewne ograniczenia wiążące się z przestrzennością wizualizowanych struktur, dając możliwość oceny kości wyrostka zębodołowego jedynie w wymiarze mezjalno-dystalnym. Wadą tej metody jest także trudność w osiągnięciu powtarzalności uzyskanych obrazów, pomimo zastosowania techniki kąta prostego, minimalizującej ryzyko wydłużenia czy skrócenia badanych struktur [28].

\section{Testy manualne}

Test manualny jest subiektywną metodą, polegającą na przykładaniu trzonków dwóch standardowych instrumentów diagnostycznych prostopadle do wszczepu i wywoływaniu nacisku o sile ok. 500 g. Zgodnie ze skalą ruchomości wszczepu śródkostnego (IM) o całkowitej stabilizacji implantu świadczy wartość IM = 0 (Tabela 1) [29].

Odmianą testu manualnego, niewymagającą użycia specjalistycznych sprzętów, jest subiektywna metoda palpacyjna, polegająca na naciskaniu wprowadzonego wszczepu palcami i próbie wykrycia ruchomości implantu. Oba te testy w bardzo niemiarodajny sposób oceniają integrację implantu i nie powinny być stosowane jako jedyna metoda pomiaru osteointegracji implantów, poprzedzająca fazę protetyczną terapii implantoprotetycznej.

\section{Metody akustyczne}

Inną metodą pomiaru stabilności implantu, równie subiektywną i zależną od doświadczenia lekarza jak opisane powyżej, jest test opukowy. Za stabilny uznaje się wszczep, który, opukiwany instrumentem diagnostycznym, wydaje wysokie, czyste dźwięki. O negatywnym wyniku badania świadczy natomiast niski, głuchy (tłumiony) dźwięk, wydawany przez wzbudzony opukiwaniem implant [30]. 


\section{Pomiary z zastosowaniem urządzenia Periotest}

Periotest jest urządzeniem służącym do miarodajnej oceny ruchomości zębów, wokół których stwierdza się stan zapalny przyzębia. Znajduje on zastosowanie także przy określaniu stopnia integracji implantów z kością wyrostka zębodołowego. Jego działanie opiera się na pomiarze przyspieszenia i czasu kontaktu młoteczka z koroną kliniczną zęba bądź z łącznikiem implantu dentystycznego. Prędkość wyhamowania młoteczka skorelowana jest ze stabilnością zęba lub wszczepu: im szybciej nastąpi jego zatrzymanie, tym większą stabilnością odznacza się badany obiekt [31]. Uzyskane wyniki przetwarzane są w skalę PTV, której wartości mieszczą się w przedziale od -8 do +50 . W terapii implantologicznej zastosowanie ma zakres od -8 do 0 [32], a o nieruchomości wszczepu i właściwej osteointegracji świadczy wynik poniżej 0 . Z licznych doświadczeń wynika jednak, że górna granica podlega wahaniom w zależności od typu kości, klasyfikowanej wg Mischa, dostarczając nie zawsze istotną dla klinicysty informację [33-37]. Na uzyskane wyniki w skali PTV wpływ ma nie tylko jakość tkanki kostnej, w którą wpro-

Tabela 2. Skala PTV (Perio Test Value)

Table 2. PTV (Perio Test Value) scale

\begin{tabular}{|l|c|}
\hline \multicolumn{1}{|c|}{ Wartość PTV } & Stopień ruchomości zęba/implantu \\
\hline od -8 do +9 & 0 \\
\hline od +10 do +19 & I \\
\hline od +20 do +29 & II \\
\hline od +30 do +50 & III \\
\hline
\end{tabular}

1.

2.

3.

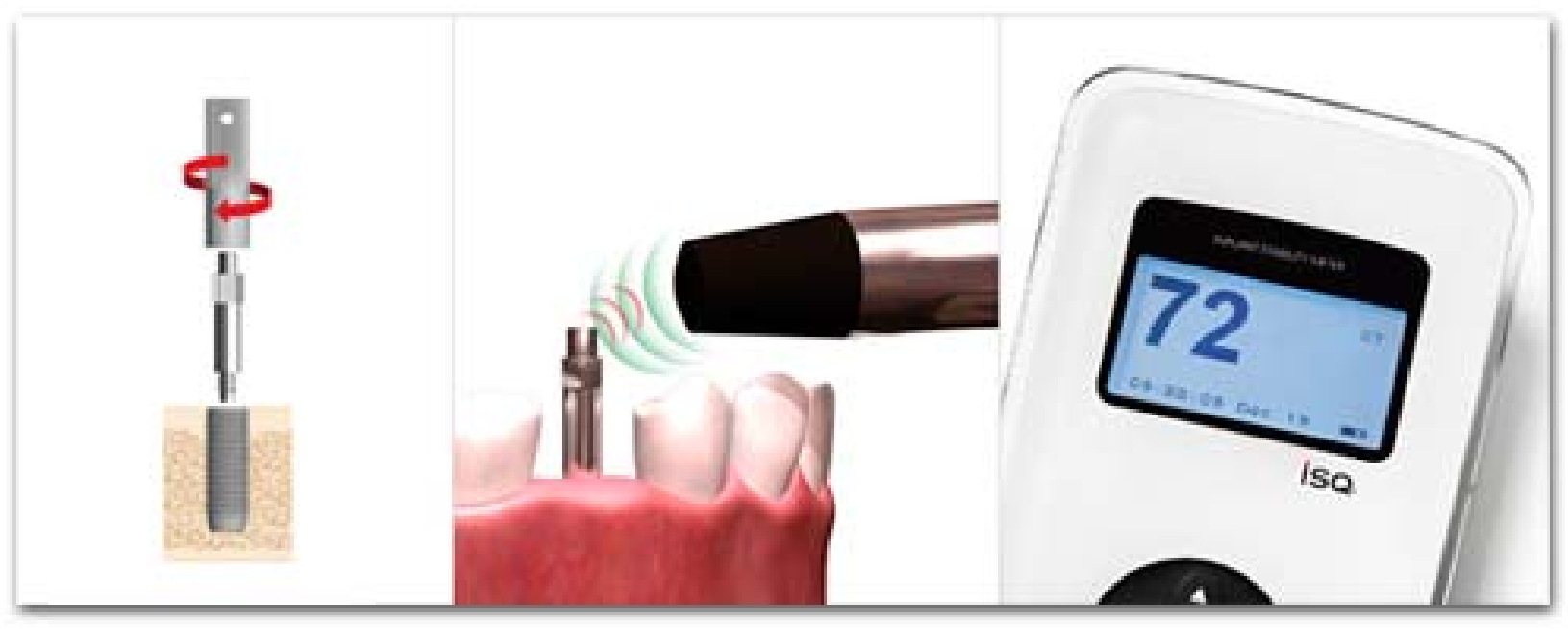

wadzony jest implant, ale również wymiar pionowy wyrostka zębodołowego oraz właściwości geometryczne i rodzaj powierzchni implantu dentystycznego [22]. Mimo niedoskonałości urządzenia zwanego Periotestem, wydaje się on być wiarygodnym, obiektywnym i niezbyt skomplikowanym w użyciu narzędziem pozwalającym na monitorowanie leczenia implantologicznego poprzez ocenę ewentualnych zmienności wyników stabilności wszczepu. Pamiętać jednak należy, aby Periotest nie stanowił jedynej metody pomiaru stabilizacji implantu, a był uzupełniany o inne środki oceny integracji wszczepu z kością.

\section{Pomiary z zastosowaniem urządzenia Osstell} Osstell jest narzędziem stworzonym do diagnozowania i prognozowania stabilności wszczepu śródkostnego, zarówno podczas zabiegu implantacji, jak i przed obciążeniem wszczepu nadbudową protetyczną. Jego działanie polega na analizie częstotliwości rezonansowej drgań, w jakie wprawiany jest wszczep śródkostny na skutek stymulacji końcówki pomiarowej umieszczonej na implancie impulsami magnetycznymi pochodzącymi z instrumentu Osstell. Częstotliwość rezonansu magnetycznego czujnika przykręconego do wszczepu zależna jest od stabilności implantu. Wynik przetwarzany jest w skalę ISQ (Implant Stability Quotient), która określa zakres wartości stabilizacji implantu, wskazując na sukces lub niepowodzenie obciążenia wszczepu śródkostnego. Skala ISQ wynosi 1-100 jednostek ISQ, a o dobrej stabilizacji implantu świadczy wynik powyżej 55 ISQ. Czujki magnetyczne przykręcane do implan-

Rycina 1. Instrument do badania stabilności implantów Osstell. 1 - końcówka SmartPeg umieszczona w wewnętrznym gwincie implantu; 2 - wysyłanie impulsów magnetycznych z Osstell do SmartPegu; 3 - poziom stabilności implantu w skali ISQ (Implant Stability Quotient)

Figure 1. Instrument for implant stability evaluation (Osstell). 1 - SmartPeg probe inserted in inner implant thread; 2 sending magnetic impulses from Osstell to SmartPeg; 3 - implant stability level on ISQ (Implant Stability Quotient) 


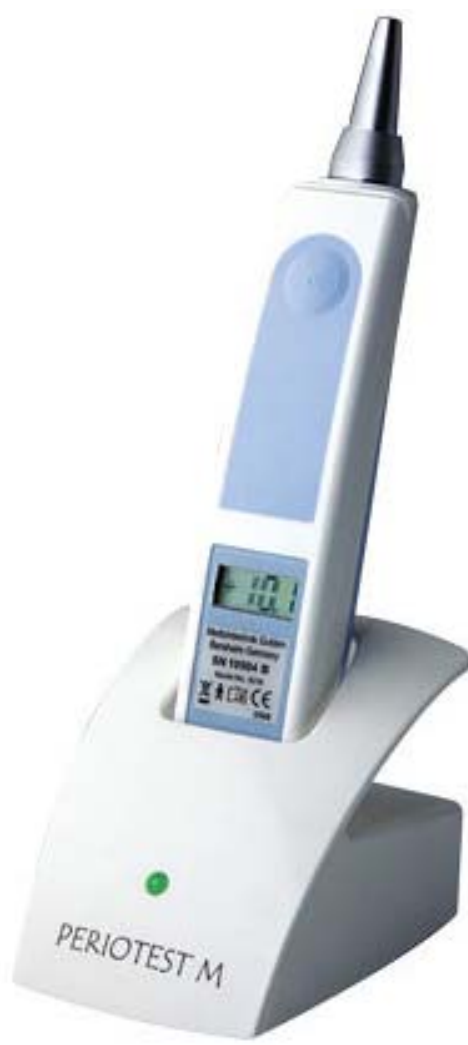

Rycina 2. Urządzenie Periotest

Figure 2. Periotest instrument

tu są kalibrowane, w zależności od rodzaju stosowanego systemu implantologicznego, tak aby wszystkie pokazywały porównywalne wartości dla tej samej stabilności implantu [38].

Wielu autorów uważa Osstell za wiarygodne i obiektywne narzędzie umożliwiające powtarzalne, precyzyjne i nieinwazyjne badanie stabilności implantu w każdym momencie jego wgajania w kość wyrostka zębodołowego [39-43], niemniej jednak opisywane są pewne wady cechujące urządzenie Osstell. Metoda ta określa bowiem tylko wartość stabilizacji implantu, a nie stopień jego osteointegracji, gdyż test ten ocenia częstotliwość rezonansową kompleksu implant-tkanka kostna [44]. Innym ograniczeniem tej metody pomiarowej jest fakt, iż jest ona możliwa do przeprowadzenia tylko w przypadku niecementowanych prac protetycznych, wymaga bowiem dostępu do tytanowego wszczepu dentystycznego [30, 31]. Podsumowując, można zatem stwierdzić, że urządzenie Osstell jest przydatnym narzędziem w pracy klinicysty, ponieważ umożliwiając ocenę stabilności wszczepu śródkostnego ułatwia podjęcie decyzji o momencie obciążenia implantu odbudową protetyczną. Jednakże metoda ta, jak każda inna, powinna być wspierana zarówno doświadczeniem lekarza, jak i innymi, dostępnymi na rynku metodami pomiaru stabilności wszczepów śródkostnych, aby zminimalizować ryzyko niepowodzenia terapii implantoprotetycznej.

\section{Podsumowanie}

Sukces terapii implantoprotetycznej jest oparty na wieloczynnikowym procesie, a osiągnięcie stabilizacji implantu jest kluczowym zjawiskiem dla powodzenia tego rodzaju rekonstrukcji narządu żucia. Ocena stabilności implantów dentystycznych stanowi więc ważny etap leczenia wykorzystującego wszczepy śródkostne. Szereg dostępnych na rynku narzędzi i metod pozwala skutecznie monitorować stabilizację pierwotną i wtórną implantów dentystycznych, umożliwiając lekarzowi kontrolę stanu śródkostnych wszczepów w kości wyrostka zębodołowego. Należy jednak mieć na uwadze, że żadna $z$ opisanych metod nie spełnia wszystkich warunków stawianych idealnemu przyrządowi służącemu do oszacowania stabilności implantów, a wybór powinien być uzależniony od konkretnej sytuacji klinicznej i indywidualnych uwarunkowań anatomicznych pacjenta. Należy mieć świadomość, że w/w metody stanowią narzędzie pomocnicze dla podjętego planu leczenia i nie mogą zastępować doświadczenia i wiedzy lekarza implantologa, który spotkał się ze zróżnicowanymi warunkami podłoża i różnymi rodzajami śródkostnych wszczepów i posiada własne „wyczucie zabiegowe”.

\section{Oświadczenia}

\section{Oświadczenie dotyczące konfliktu interesów}

Autorzy deklarują brak konfliktu interesów w autorstwie oraz publikacji pracy.

\section{Źródła finansowania}

Autorzy deklarują brak źródeł finansowania.

\section{References}

[1] Albrektsson T, Branemark P, Hansson HA, Lindstrom J. Osseointegrated Titanium Implants: Requirements for Ensuring a Long-Lasting, Direct Bone-to-Implant Anchorage in Man. Acta Orthop Scand. 1981;52:2.

[2] Rabel A, Kohler SG, Schmidt-Westhausen AM. Clinical study on the primary stability of two dental implant systems with resonance frequency analysis. Clin Oral Investig. 2007;11:257-265.

[3] Trisi P, Rao W, Rebaudi A. A histometric comparison of smooth and rough titanium implants in human low-density jawbone. Int J Oral Maxillofac Implants. 1999 Sep-Oct;14(5):689-698.

[4] Yun-Ho Kim, Na-Rae Choi, Yong-Deok Kim. The factors that influence postoperative stability of the dental implants in posteriori edentulous maxilla. Maxillofac Plast Reconstr Surg. 2016 Dec;39(1):2.

[5] Javed F, Romanos GE. The role of primary stability for successful immediate loading of dental implants. A literature review. J Dent. 2010 Aug;38(8):612-620.

[6] Stupka M, Majewski P. Poimplantacyjna stabilizacja wtórna wszczepów filarowych jako jeden z elementów oceny warunków do rozpoczęcia etapu zaopatrzenia protetycznego - możliwe powikłania. Implantoprotetyka. 2009 $\mathrm{X} ; 4(37): 14-16$. 
[7] Seong WJ, Holte EH, Holtan JR, Olin PS, Hodges JS, Ko CC. Initial stability measurement of dental implants placed in different anatomical regions of fresh human cadaver jawbone. J Prosthet Dent. 2008;6:425-434.

[8] Turkyilmaz I, et al. Two alternative surgical techniques for enhancing primary implant stability in the posterior maxilla: a clinical study including bone density, insertion torque, and resonance analysis data. Clin Implant Dental Relat Res. 2008;12:231-237.

[9] Dos Santos MV, Elias CN, Cavalcanti Lima JH. The effects of superficial roughness and design on the primary stability of dental implants. Clin Implant Dent Relat Res. 2011 Sep;13(3):215-223.

[10] Marquezan M, Osório A, Sant'Anna E, Souza MM, Maia L. Does bone mineral density influence the primary stability of dental implants? A systemic review. Clin Oral Implants Res. 2012 Jul;23(7):767-774.

[11] Naroa Lozano-Carrascal, Oscar Salomó-Coll, Marta Gilabert-Cerdà, Nuria Farré-Pagés, Jordi Gargallo-Albiol, Federico Hernández-Alfaro. Effect of implant macro-design on primary stability: A prospective clinical study. Med Oral Patol Oral Cir Bucal. 2016 Mar;21(2):e214-e221.

[12] Maciejewska I, Nowakowska J, Bereznowski Z. Osteointegracja wszczepów zębowych - etapy gojenia kości. Praca poglądowa. Prot Stomat. 2006;LVI(3):214-219.

[13] Cehreli MC, Kokat AM, Comert A, Akkocaoglau M, Tekdemir I, Akca K. Implant stability and bone density: assessment of correlation in fresh cadavers using conventional and osteotome implant sockets. Clin Oral Implant Research. 2009 Oct;20(10):1163-1169.

[14] Brandt HH. Wprowadzenie do implantologii. Urban \& Partner. 1998;2(2):22-26.

[15] Schroeder A, Van Der Zypen E, Stich H, Sutter F. The reactions of bone, connective tissue, and epithelium to endosteal implants with titanium-sprayed surfaces. J Maxillofac Sur. 1981;9(1):15-25.

[16] Frank S, Jodko M, Wojtowicz A. Ocena porównawcza stabilizacji pierwotnej implantów stomatologicznych Comparative assessment of primary dental implant stability. Dental Forum. 2012;1(XXXX):75-81.

[17] Lozano-Carrascal N, et al. Effect of implant macro-design on primary stability: A prospective clinical study. Med Oral Patol Oral Cir Bucal. 2016;21(2).

[18] Majewski P. Uwarunkowania procesu osteointegracji i implantologii stomatologicznej. Mag Stomat. 1998;8(VIII):32-36.

[19] Mohlhenrich SC, Heussen N, Elvers D, Steiner T, Holzle F, Modabber A. Compensating for poor primary implant stability in different bone densities by varying implant geometry: a laboratory study. Int J Oral Maxillofac Surg. 2015 Dec;44(12):1514-20.

[20] Gładkowski, Łomżyński, Okoński. Metody oceny stabilności stomatologicznych wszczepów śródkostnych. Implantoprotetyka. 2008 IX;2(31).

[21] Glauser R, Sennerby L, Meredith N, Rée A, Lundgren A, Gottlow J, Hämmerle $\mathrm{CH}$. Resonance frequency analysis of implants subjected to immediate or early functional occlusal loading. Clin Oral Implants Res. 2004;15(15):428-434.

[22] Morawiec T, Srebrzyńska A, Krywult A ,Koszowski R. Metody określania stabilizacji wszczepów zębowych. Przegląd piśmiennictwa. Mag Stomat. 2008;9:82-85.

[23] Jakubowski M. Przygotowanie pacjenta do leczenia implantoprotetycznego. Mag Stomat. 2008:2:20.

[24] Koczorowski R, Bielińska M, Pieńkowska K. Niektóre wykładniki oceny sukcesu terapii implantoprotetycznej. Stomat Wpółcz. 2011;2:31-38.

[25] De Vos W, Casselman J, Swennen GRJ. Cone-beam computerized tomography (CBCT) imaging of the oral and maxillofacial region: A systematic review of the literature. Int J Oral Maxillofac Surg. 2009;38:609.

[26] Różyło-Kalinowska I, Różyło TK. Zastosowanie obrazowania wolumetrycznego w ogólnej diagnostyce stomatologicznej. Mag Stomat. 2009;5:18.

[27] Wojtowicz A, Kryst L, Chaberek S. Nieinwazyjna metoda oceny przebudowy tkanki kostnej przy wykorzystaniu fourierowskiej analizy obrazu: po wszczepieniu masy płytkowej i Bio-Oss oraz wokół implantów. Implantoprotetyka. 2002 III;3:4-9.

[28] White SC, Pharoah MJ. Radiologia Stomatologiczna. Lublin: Czelej; 2002; Implanty ustno-twarzowe. s. 639-651.

[29] Sokalski J, Zagalak R. Kryteria sukcesu terapeutycznego a powikłania zabiegów implantologicznych. Twój Mag Med Stom i Prot. 2002;2:21.

[30] Vidyasagar L, et al. Dental implant stability at stage I and II surgery as measured using resonance frequency analysis. Baltic Dent Maxillifac J. 2004;6:67-72.

[31] Dario LJ, Cucchario PJ, Deluzio AJ. Electronic monitoring of dental implant osseointegration. J Am Dent Assos. 2002;133(4):483-490.

[32] Tomikowski J, Tomikowska K. Periotest w diagnostyce klinicznej implantów zintegrowanych z kością. Implantoprotetyk. $2005 \mathrm{Vl} ; 4: 5-8$.

[33] Leda, Gajdus, Hędzelek. Metody oceny stabilizacji wszczepów dentystycznych na podstawie przeglądu piśmiennictwa. Część II - metody nieinwazyjne. Prot Stomat. 2014;LXIV(6):433-442.

[34] Truhlar RS, Morris HF, Ochi S. Stability of the bone-implant complex. Results of longitudinal testing to 60 months with the Periotest device on endosseous dental implants. Ann Periodontol. 2000 Dec;5(1):42-55.

[35] Teerlinck J, Quirynen M, Darius P, van Steenberghe D. Periotest: an objective clinical diagnosis of bone apposition toward implants. Int J Oral Maxillofac Implant. 1991;6(1):55-61.

[36] Morris HE, Ochi S, Crum P, Orenstein I, Plezia R. Bone density: its influence on implant stability after uncovering. J Oral Implantol. 2003;29(6):263-269.

[37] Aparicio C. The use of the PTV value as initial success criteria of an implant: 8-year report. Int J Periodont Res Dent. 1997;17(2):150-161.

[38] Ersanli S, Karabuda C, Beck F, Leblebicioglu B. Resonance frequency analysis of one-stage dental implant stability during the osseointegration period. J Periodontol. 2005 Jul;76(7):1066-71.

[39] Sennerby L. Meredith N. Implant stability measurements using resonance frequency analysis: Biological and biomechanical aspects and clinical implications. Periodontology 2000. 2008;47:51-66.

[40] Valderrama P, Oates T, Jones A, Simpson J, Schoolfield J, Cochran D. Evaluation of two different resonance frequency devices to detect implant stability: A clinical trial. J Periodontology. 2007;78:262-272.

[41] Garg A. Osstell Mentor: Measuring Dental Implant Stability at Placement, Before Loading and After Loading. Dent Implantol. Update. 2007;18(7).

[42] Lopez A, Martinez J, Pelayo J, Garcia C, Diago M. Resonance frequency analysis of dental implant stability during the healing period. Med Oral Patol Oral Cir Bucal. 2008;13(4):244-7.

[43] Satwalekar P, Nalla S, Reddy R, Chowdary SG. Clinical evaluation of osseointegration using resonance frequency analysis. J Ind Prosthodont Soc. 2015 Jul-Sep; 15(3):192-9.

[44] Nedir R, et al. Predicting osseointegration by means of implant primary stability. A resonance frequency analysis study with delayed and immediately loaded ITI SLA implants. Clin Oral Implants Res. 2004;15(5):520-528.

Zaakceptowano do edycji: 2016-09-12 Zaakceptowano do publikacji: 2016-11-22

Adres do korespondencji: Collegium Stomatologicum UMP ul. Bukowska 70, 60-812 Poznań tel.: +48 618547050 e-mail: rkoczor@ump.edu.p 